\title{
Weed species richness, density and relative abundance on farms in the subtropical grain region of Australia
}

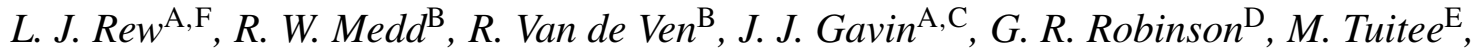 \\ J. Barnes ${ }^{\mathrm{E}}$ and S. Walker ${ }^{\mathrm{D}}$ \\ A NSW Department of Primary Industries, Tamworth Agricultural Institute, Tamworth, NSW 2340, Australia. \\ ${ }^{B}$ NSW Department of Primary Industries, Orange Agricultural Institute, Forest Road, Orange, NSW 2800, Australia. \\ ${ }^{\mathrm{C}}$ Present address: South Australian Department Water, Land and Biodiversity Conservation, PO Box 357 , \\ Port Augusta, SA, 5700, Australia. \\ DDepartment of Primary Industries, PO Box 2282, Toowoomba, Qld 4350, Australia. \\ ${ }^{\text {E}}$ Primary Industries and Fisheries, PO Box 23, Kingaroy, Qld 4610, Australia. \\ ${ }^{\mathrm{F}}$ Corresponding author. Email: lrew@montana.edu
}

\begin{abstract}
Weed management is one of the most important economic and agronomic issues facing farmers in Australia's grain regions. Weed species occurrence and abundance was monitored between 1997 and 2000 on 46 paddocks (sites) across 18 commercial farms located in the Northern Grain Region. The sites generally fell within 4 disjunct regions, from south to north: Liverpool Plains, Moree, Goondiwindi and Kingaroy. While high species richness was found (139 species or species groups), only 8 species occurred in all 4 regions and many (56 species) only occurred at 1 site or region. No species were observed at every site but 7 species (Sonchus spp., Avena spp., Conyza spp., Echinochloa spp., Convolvulus erubescens, Phalaris spp. and Lactuca serriola) were recorded on more than $70 \%$ of sites. The average number of species observed within crops after treatment and before harvest was less than 13. Species richness tended to be higher in winter pulse crops, cotton and in fallows, but overall was similar at the different sampling seasons (summer $v$. winter). Separate species assemblages associated with the Goondiwindi and Kingaroy regions were identified by correspondence analysis but these appeared to form no logical functional group. The species richness and density was generally low, demonstrating that farmers are managing weed populations effectively in both summer and winter cropping phases. Despite the apparent adoption of conservation tillage, an increase in opportunity cropping and the diversity of crops grown (13) there was no obvious effect of management practices on weed species richness or relative abundance. Avena spp. and Sonchus spp. were 2 of the most dominant weeds, particularly in central and southern latitudes of the region; Amaranthus spp. and Raphanus raphanistrum were the most abundant species in the northern part of the region. The ubiquity of these and other species shows that continued vigilance is required to suppress weeds as a management issue.
\end{abstract}

\section{Introduction}

Weeds have been identified by farmers in all 3 major graingrowing regions of Australia as their single most important land management issue (Alemseged et al. 2001). One of these regions, the Northern Grain Region (NGR), covers the subtropical cropping areas of northern NSW, north of $32^{\circ} \mathrm{S}$ latitude, and Queensland. It has summer-dominant but variable rainfall, a hot climate and naturally fertile soils. The rainfall pattern provides the basis for both summer and winter crops to be grown in rotations (Webb et al. 1997). The environment favours an extensive weed flora with over 50 species listed as being a problem by farmers (Martin et al. 1988), while Felton et al. (1994) recorded over 100 species in a summer survey of commercial paddocks, and Wicks et al.
(2000) recorded 80 weed species on 4 sites when comparing fallow management treatments.

Historically, growers in the NGR have predominantly used a bread wheat (Triticum aestivum)-sorghum (Sorghum bicolor) rotation, producing 2 crops in 3 years, with fallow periods varying from 6 to 18 months between crops. While this approach has provided reliable disease and weed control, it can result in wasteful water management (Hayman et al. 1996). Opportunity cropping, which involves sowing a crop whenever soil water reserves are adequate, has been suggested as a better alternative (e.g. Hayman et al. 1996). Consequently, farming systems in the region have diversified considerably with an increase in the range of summer and winter crops grown (Cooper 1999). Nevertheless, bread 
wheat remains the dominant winter crop and minor crops include other cereals [durum wheat (Triticum durum), barley (Hordeum vulgare) and oats (Avena sativa)], or grain legumes [chickpea (Cicer arietinum) and faba bean (Vicia $f a b a)$ ]. Alternatives to sorghum, the dominant summer crop, include dryland cotton (Gossypium hirsutum), sunflower (Helianthus annuus), maize (Zea mays) and the grain legumes [soybean (Glycine max), mungbean (Vigna radiata) and navy bean (Phaseolus vulgaris)]. Simultaneously with crop diversification, conservation tillage systems have been progressively replacing conventional tillage systems over the past 2 decades as the preferred soil preparation method. Provided crop and fallow management follow best practices, conservation tillage greatly increases grain yield through both better water storage and water use efficiency (Radford et al. 1995). Other advantages of these developments include increased profits, reduced risk of soil erosion, reduction in through-drainage of water for better salt management and the ability to better target specific weeds, such as Avena spp. or summer grasses, with more diverse herbicide options.

One disadvantage of the diversification of rotations and adoption of conservation tillage is the increased reliance on herbicides. Some herbicides have residual properties so, in order to ensure that future cropping choices are not restricted, herbicides have to be chosen carefully and with the aim of avoiding potential phytotoxic conflicts in subsequent crops (Jettner et al. 1999; Walker et al. 2000). A further concern with the increased reliance on herbicides to manage weeds both in the fallow and in-crop is the rising incidence of herbicide resistant weed populations in the region (Adkins et al. 1997; Storrie and Walker 1999; O’Donnell et al. 2002). This has lead to an increased emphasis on integrated weed management and the need for sustainable herbicide rotations to avoid heavy reliance on chemicals with similar modes of action.

Furthermore, the growth and maturation of weeds under the subtropical conditions is rapid. Many species have staggered recruitment patterns and this in conjunction with short life cycles increases the chances of weeds surviving to maturity and producing seeds. Limiting seed production of weed escapes is now recognised as a key goal of weed management programs (Jones and Medd 2000; Medd 1997), and adds emphasis to the planning of weed management programs and the timing of operations.

The study reported here arose from concerns about the increasing complexity of weed management in cropping systems in the NGR, and the realisation that a better understanding of the weed species and assemblages and associated control problems is needed to identify areas requiring future research. Previously, many weed studies in the NGR concentrated on fallow weeds and did not fully reflect the complexity of on-farm weed problems. The reported work had the objective of monitoring weeds on commercial paddocks in the NGR, through winter and summer cropping as well as fallow cycles for over 3 years, to obtain a better understanding of the weed species spectrum and abundance.

\section{Materials and methods \\ Location of sites}

Paddocks on 18 farms were monitored in 4 disjunct regions of the NGR, 8 on the Liverpool Plains (L), 3 south of Moree (M), 4 north of Goondiwindi (G) and 3 south of Kingaroy (K), from May 1997 until July 2000. These 4 disjunct regions of the NGR are referred to as regions hereafter. A total of 3 paddocks were sampled on each of the collaborating $\mathrm{L}$ and $\mathrm{M}$ properties, with 1 paddock in each part of the notional wheat-sorghum and long fallow rotation. The exception was $1 \mathrm{M}$ farm where 4 paddocks were sampled. In the $\mathrm{G}$ region participating farmers followed a more continuous winter cereal regime, whereas a more opportunistic and multiple cropping regime was monitored on the participating $\mathrm{K}$ farms. A total of 2 paddocks per farm were sampled in the $\mathrm{G}$ region and on 1 of the $\mathrm{K}$ farms. At the 2 remaining $\mathrm{K}$ farms, only 1 paddock per farm was assessed. There was a total of 46 paddocks (sites) sampled overall. The L, M and G sites were located on predominately deep heavy grey vertisols (cracking clays) and the K sites on strongly structured red krasnozem or euchrozem soils.

\section{Sampling scheme}

At each site, parallel transects located $20 \mathrm{~m}$ apart were established. Each transect was $100 \mathrm{~m}$ long, with 4 permanent quadrats $(10 \times 1 \mathrm{~m})$ placed at 20-m intervals along each transect. At the $L$ and $M$ sites 4 such transects were used (providing 16 quadrats), while only 3 transects were established at the $\mathrm{G}$ and $\mathrm{K}$ sites, giving 12 quadrats. To ensure accurate and easy repositioning of transects, distances from static landmarks (e.g. fence posts, trees) were generally recorded, along with grid coordinate readings from differential global positioning systems (DGPS, Magellan GPS Systems, Australia).

Weeds were identified and individual species densities assessed within each $10 \mathrm{~m}^{2}$ quadrat using a scoring system involving 8 categories (Table 1). This involved visually estimating the density of each species within a quadrat and assigning it a score. A more detailed description of the scoring system and its validation is given by Rew et al. (2000). Species nomenclature follows the Flora of NSW (Harden 1990, 2002), and several handbooks were consulted to aid identification in the field.

Quadrats at all sites were assessed 2-3 times during the cropping phase; within 6-8 weeks of sowing (post-sowing) and again 1-3 weeks before harvest (pre-harvest). If post-emergence herbicides were applied to the crop, an assessment was made 4 weeks after application

Table 1. Scoring system used for estimating weed density of species observed within $10 \mathrm{~m}^{2}$ quadrats and the assigned mid-range density value used in data analysis

\begin{tabular}{lcc}
\hline Score category & $\begin{array}{c}\text { Range } \\
\left.\text { (plants/10 } \mathrm{m}^{2}\right)\end{array}$ & $\begin{array}{c}\text { Mid-range density } \\
\left.\text { (plants } / 10 \mathrm{~m}^{2}\right)\end{array}$ \\
\hline 0 & 0 & 0.0 \\
1 & $1-6$ & 3.5 \\
2 & $7-20$ & 14.5 \\
3 & $21-60$ & 40.5 \\
4 & $61-190$ & 125.5 \\
5 & $191-600$ & 400.5 \\
6 & $601-6000$ & 3300.0 \\
7 & $>6000$ & 10000.0 \\
\hline
\end{tabular}


(post-emergent). The sites were also assessed before sowing (presowing) and after harvest (post-harvest) whenever conditions promoted weed emergence.

\section{Data collation and analyses}

A database of information and records compiled by farm, paddock/site, region, year, season, crop species or fallow, tillage regime, sampling time, herbicide treatments, species occurrence and density categories facilitated the spatial and temporal collation and tabulation of crops grown and species richness over time.

Correspondence analysis (CA; ter Braak 1995) was used to analyse an aspect of the data, as this method has proven very useful in situations with high species turnover (high $\beta$ diversity) over a large range of environmental conditions; exactly the situation observed in our field survey. With CA, it is assumed that species respond unimodally to underlying environmental gradients. That is, each species has an optimal position on a particular environmental gradient and responds less favourably further away from this optimum. For this study the CA was restricted to presence/absence data, forming a 139 weed species by 46 sites array with the $(i, j)$ cell of the array $(i=1, \ldots, 139$ and $j=1, \ldots, 46)$ taken as one if species $i$ was observed at site $j$ at least once during the survey, and zero otherwise.

Ordination techniques such as CA are a convenient way of summarising multivariate data into easy to interpret scatter diagrams or, more ambitiously, to uncover the underlying structure of the data (Jongman et al. 1995). In our analysis we also investigated, to an extent, the removal of rare species from the dataset as their inclusion may affect the ordination (Kenkel et al. 2002; McCune and Grace 2002). All CA analyses were performed in R (Ihaka and Gerileman 1996), a free, open source statistical environment, using the Vegan: Community Ecology Package (freely available at http://cc.oulu.fi/ jarioksa/softhelp/vegan.html).

For analysis of species density and abundance the individual quadrat scores were converted into counts, replacing each species score in a quadrat with its approximate mid-range value, except for score values of 7 which were given a density of 10000 (Table 1). Mean densities were then determined for each site at each sampling time, averaging over all quadrats. The relative abundance ( $\left.r_{\mathrm{ab}}\right)$, defined by Derksen et al. (1994), was then calculated for each species within each region separately. The relative abundance value $\left(r_{\mathrm{ab}}\right)$ gives an equally weighted measure of relative frequency and relative incidence. To calculate $r_{\mathrm{ab}}$ for a species (i) in a particular region let $X_{i j}$ denote the mean density of species group $i$ at site/sampling time $j$ within the particular region and let $Y_{i j}$ equal 1 if $X_{i j}$ is greater than zero and 0 otherwise (i.e. $Y_{i j}$ is an indicator variable). Then, the relative abundance $\left(r_{\mathrm{ab}}\right)$ of species group $i$ for a particular region is calculated as:

$$
r_{\mathrm{ab}}(i)=\frac{1}{2}\left(\frac{\sum_{j} X_{i j}}{\sum_{i j} X_{i j}}+\frac{\sum_{j} Y_{i j}}{\sum_{i j} Y_{i j}}\right) .
$$

Here the summation is for all species $(i)$ and all sites/sampling time $(j)$ within the particular region. For each region the sum over species of the $r_{\mathrm{ab}}$ values equals 1 (i.e. $\sum_{i} r_{\mathrm{ab}}(i)=1$ ).

\section{Results}

Overall, 13 different crops were grown in the 46 sites spanning the 4 regions, though many were sown infrequently and not all were sampled (Table 2). Bread wheat was the most frequently sown winter crop followed by durum wheat. Sorghum was the most frequently sown summer crop.

At least 157 taxa were recorded across all the sites. Some species were grouped at a generic level due to difficulties in determining specific identification at the seedling stage. These are reported as genus followed by
Table 2. Number of sites sown to different crops and sampled for weeds during May 1997-July 2000

Values in parentheses are sites sown to crops but not sampled for weeds in that year. Year represents the year in which the crop was sown but not necessarily harvested

\begin{tabular}{lrlr}
\hline Crop & 1997 & 1998 & 1999 \\
\hline Winter crops & & & \\
Bread wheat & 18 & 14 & 16 \\
Durum wheat & 4 & 5 & 6 \\
Barley & 3 & 1 & 2 \\
Faba bean & 1 & 0 & 2 \\
Chickpea & 1 & $0(1)$ & 1 \\
Canola & 1 & 0 & 0 \\
Oats & 0 & 1 & 0 \\
Summer crops & & & \\
Sorghum & $8(4)$ & $7(3)$ & 13 \\
Mungbean & 0 & 2 & 0 \\
Soybean & $0(2)$ & $1(2)$ & 1 \\
Maize & $0(1)$ & 1 & 2 \\
Cotton & 0 & $1(1)$ & 2 \\
Navy bean & 0 & 0 & 1 \\
\hline
\end{tabular}

spp. for: Avena fatua and A. ludoviciana; Echinochloa crus-galli and E. colona; Epilobium billardierianum subsp. cinereum and E. hirtigerum; undetermined Euphorbia species and Chaemsyce drummondii; undetermined Euchiton/Gamochaeta species; undetermined Lepidium species and $L$. bonariense; Medicago minima and M. polymorpha var. vulgaris and undetermined Medicago species; Polygonum aviculare and P. patulum; Sonchus asper and S. oleraceus; Sisymbrium officinale, S. orientale and $S$. thellungii; and undetermined Veronica species and $V$. peregrine. Thirteen volunteer crops were recorded and included in the weed list, namely barley, chickpea, cotton, faba bean, maize, mungbean, navy bean, oats, sorghum, soybean, sunflower, bread wheat and durum wheat - the last 2 crops being grouped since they were difficult to distinguish. Including the unknown category, the resulting condensed list of 139 species or generic groups (Appendix 1), are hereafter referred to as species.

\section{Species richness}

Weed species diversity/richness for the entire study period was highest in $\mathrm{L}$ with 111 species, whilst 71 species were recorded at $\mathrm{M}, 62$ in $\mathrm{G}$ and the least diverse was $\mathrm{K}$ with 27 species. In all regions the richness consisted of species that were recorded only in a region (56 species) or species that occured in 2 ( 43 species), 3 ( 32 species) or all 4 regions (8 species) namely: Amaranthus spp., Avena spp., Lamium amplexicaule, Raphanus raphanistrum, Rapistrum rugosum, Sonchus spp., Urochloa panicoides and volunteer wheat (durum and winter wheat were grouped) (Table 3). 
Table 3. Species richness (number of species) recorded in each region (L, Liverpool Plains; M, Moree; G, Goondiwindi; K, Kingaroy) during May 1997-July 2000

The number of species occurring in a region is indicated in italics; where a species occurred in 2 or more regions it is included in each cell

\begin{tabular}{lrrrrr}
\hline & $\mathrm{L}$ & $\mathrm{M}$ & $\mathrm{G}$ & $\mathrm{K}$ & Total \\
\hline $\begin{array}{l}\text { Number of species recorded } \\
\text { only in a single region }\end{array}$ & 33 & & & & \\
& & 4 & & & \\
Number of species common & 24 & 24 & & & $\mathbf{5 6}$ \\
$\quad 11$ & & 11 & & \\
$\quad$ to 2 regions & 3 & & & 3 & \\
& & 2 & 2 & & \\
& & 1 & & 1 & \\
Number of species common & 26 & 26 & 26 & 2 & $\mathbf{4 3}$ \\
$\quad 1$ & & 1 & 1 & \\
to 3 regions & 5 & 5 & & 5 & $\mathbf{3 2}$ \\
Ubiquitous species & 8 & 8 & 8 & 8 & $\mathbf{8}$ \\
Total & $\mathbf{1 1 1}$ & $\mathbf{7 0}$ & $\mathbf{6 2}$ & $\mathbf{2 7}$ & $\mathbf{1 3 9}$ \\
\hline
\end{tabular}

The mean number of species in any region for a site at any time was less than 10 and declined, as did variability, from south (L) to north (K), when averaged across sampling times (Fig. 1a). Species richness tended to be greater in winter pulse crops, cotton and fallows than other crops (Fig. 1b), and the richness of the weed floras recorded in winter was marginally greater and more diverse than that recorded in summer periods (Fig. 1c).

Similarly, species density was highly skewed and mostly below 17 plants $/ \mathrm{m}^{2}$ in $\mathrm{L}, \mathrm{M}$ and $\mathrm{G}$ regions and mostly below 10 plants $/ \mathrm{m}^{2}$ in all crops (Fig. $1 d$ and $e$ ). Mean density was $<10 \mathrm{plants} / \mathrm{m}^{2}$ in the $\mathrm{M}$ region, slightly higher in the $\mathrm{L}$ (14) and G (16) regions and about 52 plants $/ \mathrm{m}^{2}$ in the $\mathrm{K}$ region because of high densities in some bread wheat crops. Sorghum, cotton and the summer pulse crops tended to have lower weed densities than the other crops (Fig. 1e). Thus mean weed densities observed during the winter seasons were slightly higher than those recorded during summer (Fig. $1 f$ ).

\section{Correspondence analysis - site and species separation}

Eigenvalues of $\lambda_{1}=0.458, \lambda_{2}=0.345, \lambda_{3}=0.208$, $\lambda_{4}=0.189$ and $\lambda_{5}=0.176$ were calculated for the first 5 ordination axes of the $\mathrm{CA}$, with the remaining eigenvalues declining slowly. Plots of the site scores for the first 2 axes of the CA clearly show separation of the regions into 3 distinct groups, LP/M, G and K (Fig. 2). The strong separation on these 2 axes into 3 regional groupings can be attributed in part to those species that are unique to a region or that occur infrequently. The corresponding plot of the species scores
(Fig. 3) demonstrates this point; with species affiliated with the regional groupings, and with a number of species strongly affiliated to the $\mathrm{K}$ region and others to the $\mathrm{G}$ region over the $\mathrm{LP} / \mathrm{M}$ region and vice versa.

However, ordination of species is not as clear as for the sites (Fig. 2 v. Fig. 3). Among those separated to the far right of the first ordination axis, 5 species were recorded only in the $\mathrm{K}$ region, but other species were recorded in a mixture of regions. The second axis separates some species into the bottom left corner, and 11 of those species were recorded solely in the $\mathrm{G}$ region. Another 11 species, which could be considered part of the same cluster, were recorded in a mixture of regions, which always included $G$, and 2 species that were recorded only in $\mathrm{L}$ region. The majority of species for the $\mathrm{L}$ and $\mathrm{M}$ regions show no separation on a species basis using correspondence analysis, indicating that there is a level of overlap in species occurrence and these species are mainly observed near the origin of the axes (Fig. 3). However, the tabular data reveals that 4 species were recorded only in $\mathrm{M}$ and 33 only in the $\mathrm{L}$ region (Table 3; Appendix 1).

When species that were unique to a region were excluded from the analysis, as well as species that occurred at fewer than 5 sites (leaving only 65 of the original 139 species), the first 2 axes of the restricted CA still separated the regions in the same way as the full dataset (data not shown). An examination was also undertaken of the next few CA axes, but these revealed no further clear separation of sites and/or species (data not shown), reflecting the magnitude of the corresponding eigenvalues and their slow decline. These results indicate that after accounting for regional differences, there are no dominant gradients accounting for site differences within regions; i.e. there was not dominant effects of tillage, crop rotation, weed management etc.

\section{Relative abundance of species}

Due to the regional trends identified in the correspondence analysis, $r_{\mathrm{ab}}$ values were calculated on a regional basis using sites at each sampling time as the sampling unit. Within all regions relative abundance was highly skewed with $75 \%$ or more of species having values lower than the mean (Fig. 4). Thus a few species contributed most to $r_{\mathrm{ab}}$, as indicated by the 10 species with the highest values in each region (Table 4). When combined into 1 group, these 10 most abundant species within each region gave relative abundance scores of 0.48 , $0.53,0.63$ and 0.73 for regions $\mathrm{L}, \mathrm{M}, \mathrm{G}$ and $\mathrm{K}$, respectively (Table 4).

Of the 8 species found in all 4 regions, 6 also featured among the highest $r_{\mathrm{ab}}$ values in one or more of the regions. Avena spp. and Sonchus spp. were in the top 10 highest $r_{\mathrm{ab}}$ values in $\mathrm{L}, \mathrm{M}$ and $\mathrm{G}$ regions, Lamium amplexicaule in $\mathrm{L}$ and $\mathrm{K}$ regions, Raphanus raphanistrum, Coronopus didymus and 

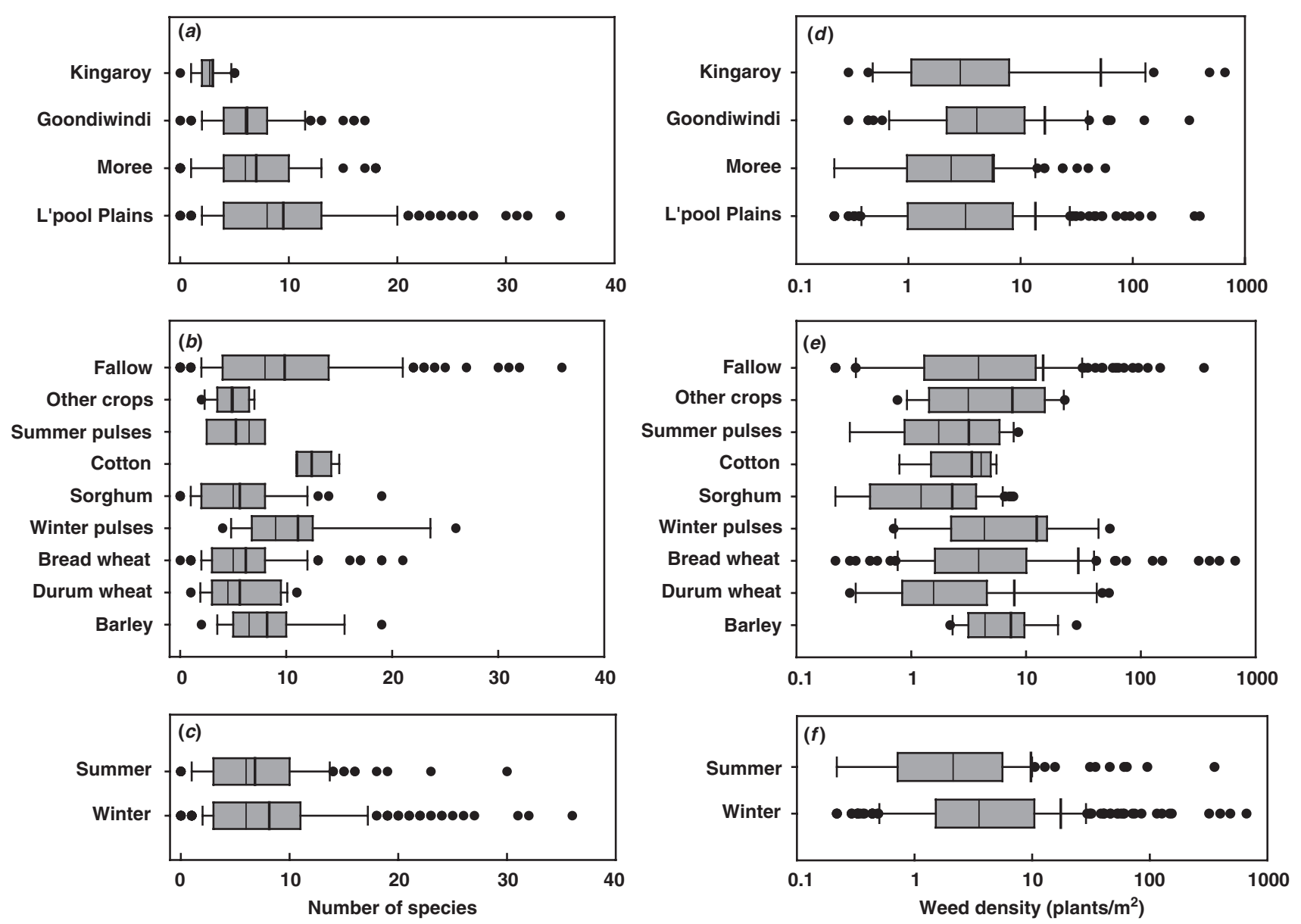

Figure 1. Box plots of species richness across $(a)$ regions, $(b)$ crops and $(c)$ sampling season and species density across $(d)$ regions, $(e)$ crops and $(f)$ sampling season (note log scale for weed density). The line within each box is the median, the heavy solid line is the mean, the box demarcates the 25 th and 75 th percentiles, error bars indicate 10th and 90th percentiles and dots are 'outliers'. L'pool Plains, Liverpool Plains region.

Amaranthus spp. in the $\mathrm{K}$ region, and Rapistrum rugosum in the $\mathrm{M}$ region (Table 4). Other species with high $r_{\mathrm{ab}}$ values in a number of regions included, Convolulus erubescens in L, M and $\mathrm{K}$, and Echinochloa spp. in L, M and G, Polygonum spp. in $\mathrm{L}$ and $\mathrm{M}$, and Phalaris paradoxa in M and G. Conversely, a few species which were recorded only in one region were also calculated to have high $r_{\mathrm{ab}}$ values including, volunteer soybean and Stachys arvensis in K, and Crassula spp. in L (Table 4), suggesting regional if not local high abundance. Volunteer sorghum and faba bean crop species also had among the 10 highest $r_{\mathrm{ab}}$ values in the M region.

The 8 species observed in all regions were also widespread across sites. Sonchus spp. were recorded at $94 \%$ of sites (Table 5), with $r_{\mathrm{ab}}$ values of $0.061,0.093,0.172,0.014$ in L, M, G and K, respectively; Avena spp. were recorded on $91 \%$ of sites with $r_{\mathrm{ab}}$ values of $0.069,0.242,0.153$ and 0.007 , for L, M, G and K, respectively (Appendix 1).

In all, 33 species occurred in 3 regions, and of these Echinochloa spp. were present at $78 \%$ of the sites with $r_{\mathrm{ab}}$ values of $0.083,0.039$ and 0.144 and Phalaris paradoxa on $76 \%$ of sites with $r_{\mathrm{ab}}$ values of $0.019,0.068$ and 0.065 for $\mathrm{L}, \mathrm{M}$ and G, respectively, C. erubescens was found at $76 \%$ of sites ( $r_{\mathrm{ab}}$ values of $0.024,0.043$ and 0.041 for L, M and K regions), and wind-dispersed species Conyza spp., Lactuca serriola and Euchiton/Gamochaeta species, occurred on 83, 74 and $70 \%$ of sites, respectively (G, L and M) but had low $r_{\mathrm{ab}}$ values (Appendix 1). A total of 42 species occurred in 2 regions.

\section{Discussion}

The diverse weed flora identified by this study in the NGR exceeded 139 species. Whilst there was no indication of weed species assemblages due to temporal or management influences, there was an indication of spatial influences. Separate assemblages of a small number of species were identified for the Kingaroy and Goondiwindi regions which both differed from the majority of species that occurred in the Moree and Liverpool Plains regions. Despite this high 


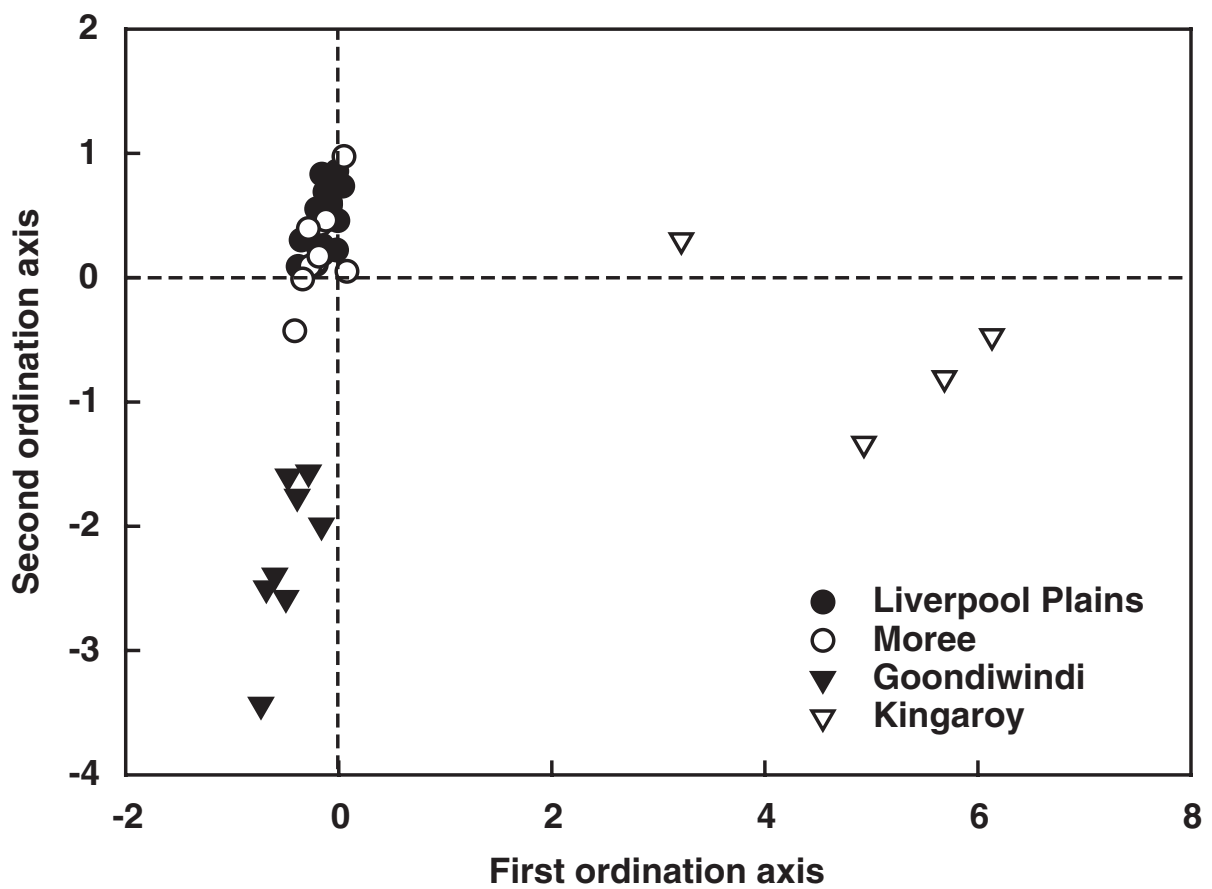

Figure 2. Correspondence analysis showing the first 2 ordination axes using sites as the dependent variable.

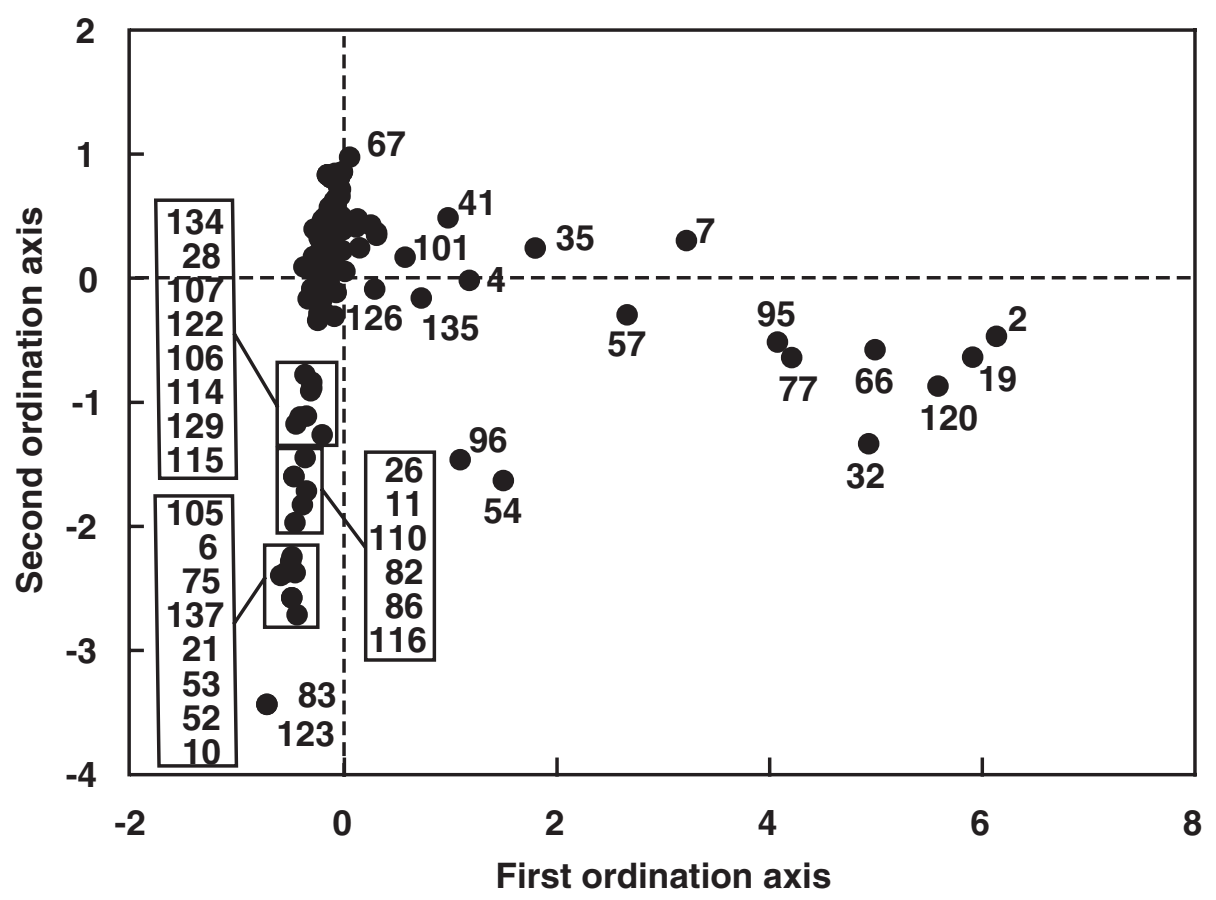

Figure 3. Correspondence analysis showing the first 2 ordination axes using species as the dependent variable. For numbered index of species see Appendix 1. Points without numbers were observed in the Liverpool Plains and Moree regions.

species richness, generally only a few species dominated at any 1 site at any single point in time.

The main species observed, if not their ubiquity, were similar to those reported from a mail and paddock surveys conducted at wheat harvest by Martin et al. (1988), paddock surveys conducted in the summer by Felton et al. (1994), and mail and field surveys conducted by Alemseged et al. (2001). Alemseged et al. (2001) reported on grain growers' views of 


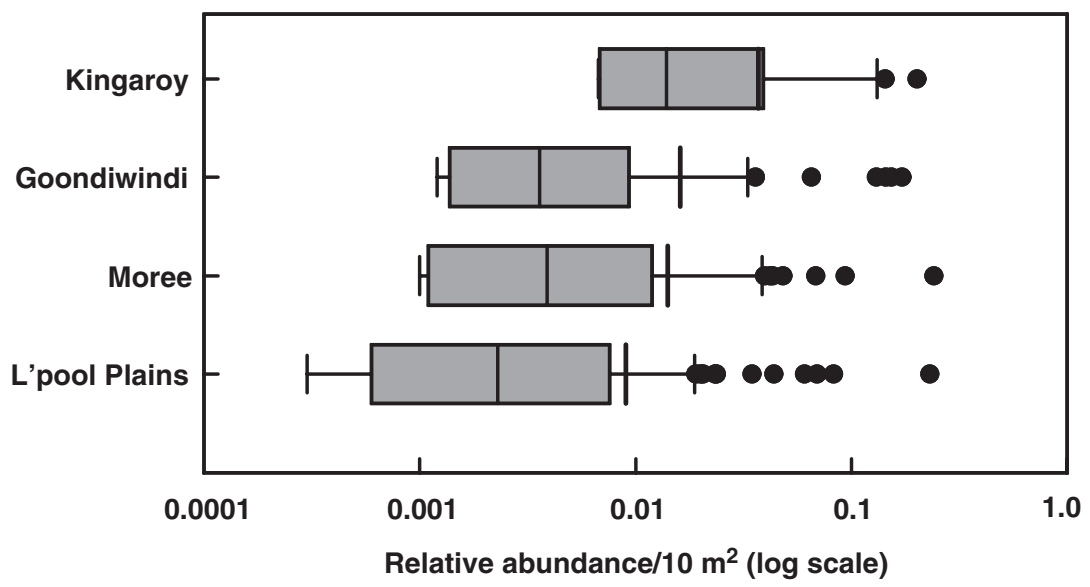

Figure 4. Box plot of species relative abundance within regions (excluding species not recorded in a region, see Appendix 1). The line within each box is the median, the heavy solid line is the mean, the box demarcates the 25th and 75th percentiles, error bars indicate 10th and 90th percentiles and dots are 'outliers'. Note log scale. L'pool Plains, Liverpool Plains region.

Table 4. Relative abundance $\left(r_{a b}\right)$ ranking of the top 10 species in each region and their combined value over the whole study period, May 1997-July 2000

\begin{tabular}{|c|c|c|c|c|c|c|c|}
\hline \multicolumn{2}{|l|}{ Liverpool Plains } & \multicolumn{2}{|l|}{ Moree } & \multicolumn{2}{|l|}{ Goondiwindi } & \multicolumn{2}{|l|}{ Kingaroy } \\
\hline Species & $r_{\mathrm{ab}}$ & Species & $r_{\mathrm{ab}}$ & Species & $r_{\mathrm{ab}}$ & Species & $r_{\mathrm{ab}}$ \\
\hline Lamium amplexicaule & 0.231 & Avena spp. & 0.242 & Sonchus spp. & 0.172 & Coronopus didymus & 0.201 \\
\hline Echinochloa spp. & 0.083 & Sonchus spp. & 0.093 & Avena spp. & 0.153 & $\begin{array}{l}\text { Raphanus } \\
\text { raphanistrum }\end{array}$ & 0.143 \\
\hline Avena spp. & 0.069 & Phalaris paradoxa & 0.068 & Echinochloa spp. & 0.144 & Lamium amplexicaule & 0.129 \\
\hline Sonchus spp. & 0.061 & Medicago spp. & 0.048 & Sisymbrium spp. & 0.130 & Stachys arvensis & 0.119 \\
\hline Crassula spp. & 0.035 & Rapistrum rugosum & 0.042 & Cirsium vulgare & 0.036 & $\begin{array}{l}\text { Convolvulus } \\
\text { erubescens }\end{array}$ & 0.041 \\
\hline Convolvulus erubescens & 0.024 & Echinochloa spp. & 0.039 & Euphorbia spp. & 0.027 & Daucus glochidiatus & 0.039 \\
\hline Lactuca serriola & 0.023 & Sorghum bicolor & 0.035 & $\begin{array}{l}\text { Euchiton and } \\
\text { Gamochaeta spp. }\end{array}$ & 0.024 & Amaranthus spp. & 0.035 \\
\hline Conyza spp. & 0.020 & Vicia faba & 0.034 & Solanum nigrum & 0.023 & Ipomoea plebeia & 0.034 \\
\hline
\end{tabular}

the most difficult to control weeds in the NGR which included, Avena spp., Brassica tournefortii, P. paradoxa, Sonchus spp., Polygonum aviculare, Lolium rigidum, Fallopia convolvulus, $R$. raphanistrum, Argemone mexicana and Arctotheca calendula. An earlier mail survey to growers by Martin etal. (1988) had resulted in a similar but not identical list of troublesome weeds, Avena spp., $R$. rugosum, $P$. aviculare, $P$. paradoxa, F. convolvulus, Silybum marianum, Carthamus lanatus, Sisymbrium orientale and Lolium spp. Some of the species perceived as the worse problems were reflected in our site ubiquity and relative abundance values for each region, for example Avena spp., P. paradoxa, Sonchus spp.,
P. aviculare, $F$. convolulus and $R$. raphanistrum but others were neither found very frequently nor at high abundance. We observed only L. rigidum, B. tournefortii, C. lanatus and A. ochroleuca at the Liverpool Plains sites. Arctotheca calendula was not recorded at any sites, although it was only ranked as an important weed by $6 \%$ of growers (Alemseged et al. 2001). Identification of the different Brassicaceae weeds was found to be poor in a separate survey (L. J. Rew, A. Storrie unpublished data) and is further confused by the use of common names. Because of these anomalies in identification, comparison of the relative importance of these species between the surveys is pointless. In our sampling R. raphanistrum and Sisymbrium species had similar relative 
Table 5. Percentage of sites $(n=46)$ on which particular species occurred during May 1997-July 2000

Only species which occurred on $50 \%$ or more sites are listed

\begin{tabular}{lc}
\hline Species & Proportion of sites (\%) \\
\hline Sonchus spp. & 93.5 \\
Avena spp. & 91.3 \\
Conyza spp. & 82.6 \\
Echinochloa spp. & 78.3 \\
Convolvulus erubescens & 76.1 \\
Phalaris paradoxa & 76.1 \\
Lactuca serriola & 73.9 \\
Euchiton and Gamochaeta spp. & 69.6 \\
Cirsium vulgare & 69.6 \\
Medicago spp. & 67.4 \\
Raphanus raphanistrum & 65.2 \\
Hypochaeris radicata & 56.5 \\
Lamium amplexicaule & 56.5 \\
Rapistrum rugosum & 56.5 \\
Silybum marianum & 54.4 \\
Sorghum bicolor & 54.4 \\
Fallopia convolvulus & 52.2 \\
Urochloa panicoides & 50.0
\end{tabular}

abundance overall, $R$. rugosum was lower and B. tournefortii the lowest.

Felton et al. (1994) surveyed 65 uncultivated fallow and 25 sorghum paddocks during the summer of 1989 and observed 87 and 51 different species, respectively. In their study, C. erubescens, E. crus-galli, U. panicoides, Panicum decompositum, Conyza spp. and $S$. oleraceus were the most ubiquitous, observed in more than $50 \%$ of fallow paddocks; C. erubescens, E. crus-galli, U. panicoides, P. decompositum, Hibiscus trionum, Portulaca oleracea, P. aviculare, Tribulus spp., Xanthium spinosum, Avena spp. and Eragrostis cilianensis were most ubiquitous (more than 50\%) in sorghum paddocks. All of these species were recorded at our sites though only $C$. erubescens, Echinochloa spp., Sonchus spp., Conyza spp., Avena spp. and $U$. panicoides were observed at more than $50 \%$ of the sites.

About 2 decades ago almost half of farmers in the southern part of the NGR followed a continuous wheat rotation, one third a wheat-sorghum rotation and about one-fifth a wheatlegume rotation (Medd et al. 1995 based on Martin et al. 1988). The general perception in the mid to late 1990s was that more farmers in the NGR region were aiming for a wheat-sorghum and long fallow rotation, growing 2 crops over 3 years. However, adhering to any rotation is often thwarted by climatic and economic volatility (Martin et al. 1988), as found in our study. A change towards more opportunity cropping and/or diverse cropping sequences is apparent given the 7 winter crops and 6 summer crops grown in what ostensibly had been nominated by the participating farmers as sites in a wheat-sorghum rotation. The fact that many farmers appear to be following a more opportunity cropping approach by incorporating information on available soil moisture and market values endorses the work of Hayman et al. (1996) and others, the extension service and decision support models such as 'Wheatman' (Woodruff 1992) even though adoption of such models been poor (Hayman and Easdown 2002).

All 13 crop species grown on sites involved in the study were observed as volunteer weeds which is characteristic of the subtropical region. Soybean attained the fifth highest relative abundance value in the Kingaroy region, and sorghum and faba bean were eight and ninth highest in the Moree region. Other than Roundup Ready cotton, which was first grown commercially in the region in 2000 after this study was completed, canola is the only other herbicide tolerant crop presently grown commercially in Australia. Only 1 site in 1 year sowed triazine resistant canola. Should herbicide tolerant crops be more widely adopted in the future, the high abundance of many of the crops as volunteers suggests that they would become a major weed issue in the NGR. Glyphosate resistant varieties would be of particular concern since glyphosate is the main chemical used during the fallow period. This supports the views and reservations about such varieties put forwards by Medd et al. (1995). Already a biotype of $L$. rigidum resistant to glyphosate has been selected for in the region (Storrie and Cook 2002), signalling the problem of over reliance on this herbicide for fallow management.

There is a perception by farmers and researchers that the increased adoption of conservation tillage practices has led to an associated change in the weed spectrum. 'Shifts in weed flora are part of the folklore of weed science and indeed have taken place throughout agricultural history' (Medd 1987). There is no indication in our study of any species shifts having occurred from either the adoption of conservation tillage or opportunity cropping. The correspondence analysis highlighted some regional trends in weed associations but as no further separation of species was readily apparent it can be inferred that particular practices, for example tillage, crop rotation or agrochemical input had no identifiable bearing on the weed flora. Nevertheless, weed assemblages observed in any paddock are purported to result from management practices (tillage, crop rotation, sowing time, row spacing, weed management practices, Buhler 2002). Climate or the introduction of seeds from areas outside the paddock (e.g. as crop seed contamination, on machinery, wind-dispersal) may also influence assemblages. Upon examination, there is nothing especially remarkable about the species assemblages separated by the correspondence analysis. Both the Goondiwindi and Kingaroy groups involved a range of annual and perennials as well as broadleaved and grass species and there appeared to be no 
functional relationship within the species groups in terms of their seasonality.

Felton et al. (1994) found that weed density and species richness was generally lower in fallow paddocks that had been treated with herbicide (glyphosate and/or atrazine) compared with fallows where tillage was practiced. While we found no evidence of cultural influences on the fallow flora, there was an indication of higher species diversity in fallows. Canadian experience has shown that weed spectrum changes cannot be related to tillage practices alone (Derksen et al. 1993). Subsequently Leeson et al. (2000) found that cropping history had the largest influence on weed communities from a survey of 28 farms and about 300 commercial fields sampled in Saskatchewan; herbicide had the second largest impact on weed species assemblages. Thus, numerous site-specific factors need to be considered before the weed assemblages or changes to assemblages can be fully explained.

Despite the diversity of management practices underlying our study the average number of species observed in a site over the study period was about 6 at any sampling time, varying slightly among regions and crops; and the median number of species observed at any sampling time was between 4 and 8 depending on the crop and sampling period. Most sites had some form of crop rotation that involved both summer and winter crops; farms in the Goondiwindi region were the exception in tending to grow wheat repeatedly. Doucet et al. (1999) asserted that crop rotation is generally perceived to reduce weed density and maintain species richness, thus preventing dominance of a few weeds, which is a possible explanation for the high species richness and generally low weed abundance observed in this study. In the NGR rainfall can occur all year around but much falls in summer storms and most rain events result in flushes of weeds. Separating the data into summer or winter crops, to differentiate species which germinate in those seasons, revealed little difference in species richness and that relative abundance values declined quite rapidly between the first, second, third and fourth most abundant species (data not shown). This suggests that a few species are dominating in the different seasons, as well as on a regional basis.

This study demonstrates that a large number of species (at least 139) are present in the NGR, although only 8 species were recorded in all 4 regions. The highest species richness was observed in the Liverpool Plains (111 species) and Moree (71) regions and may be related to their long history with livestock production that may have fostered the spread of weed propagules. Prior to the 1960s these regions were predominately grazing rangelands, at which time it became possible to crop the heavy vertisol soils due mainly to changes in tillage practices (Marcellos and Felton 1992). Interestingly, species richness was considerably lower in the Kingaroy region where continuous rotational cropping is practiced on the highly structured krasnozem type soils. Irrespective of location, the relative abundance values of most species were low, which suggests farmers were effectively managing their weeds. However, a number of different species obtained higher relative abundance values in several regions and sites demonstrating the environmental plasticity and adaptability of such species. With such a broad base to the weed flora it is reasonable to expect that regardless of the environment or cultural/management practices adopted, some species will have potential to benefit and become dominant in different crops and seasons.

\section{Acknowledgments}

Many thanks to all of the farmers who collaborated with this project and to John Hosking and Andrew Storrie at Tamworth Agricultural Institute for help with plant identification. The project was funded by the Grains Research and Development Corporation with support from NSW Agriculture. Constructive comments from 2 anonymous referees helped to improve this manuscript, particularly regarding the use of correspondence analysis.

\section{References}

Adkins SW, Wills D, Boersma M, Walker SR, Robinson G, McLeod RJ, Einam JP (1997) Weeds resistant to chlorsulfuron and atrazine from the north-east grain region of Australia. Weed Research 37, 343-349. doi: 10.1046/j.1365-3180.1997.d01-56.x

Alemseged Y, Jones R, Medd R (2001) A farmer survey of weed management and herbicide resistance problems of winter crops in Australia. Plant Protection Quarterly 16, 21-25.

Buhler DD (2002) Challenges and opportunities for integrated weed management. Weed Science 50, 273-280.

Cooper JL (1999) A grower survey of rotations used in the New South Wales cotton industry. Australian Journal of Experimental Agriculture 39, 743-755. doi: 10.1071/EA98055

Derksen DA, Lafond GP, Thomas AG, Loeppky HA, Swanton CJ (1993) Impact of agronomic practices on weed communities: tillage systems. Weed Science 41, 409-417.

Derksen DA, Thomas AG, Lafond GP, Loeppyky HA, Swanton CJ (1994) Impact of agronomic practices on weed communities: fallow within tillage systems. Weed Science 42, 184-194.

Doucet C, Weaver SE, Hamill AS, Zhang J (1999) Separating the effects of crop rotation from weed management on weed density and diversity. Weed Science 47, 729-735.

Felton WL, Wicks GA, Welsby SM (1994) A survey of fallow practices and weed floras in wheat stubble and grain sorghum in northern New South Wales. Australian Journal of Experimental Agriculture 34, 229-236.

Harden GJ (1990) 'Flora of New South Wales. Vol. 1.' (University of New South Wales Press Ltd.: Sydney)

Harden GJ (2002) 'Flora of New South Wales. Vol. 4.' (University of New South Wales Press Ltd.: Sydney)

Hayman PT, Easdown WJ (2002) An ecology of a DSS: reflections on managing wheat crops in the northeastern Australian grains region with WHEATMAN. Agricultural Systems 74, 57-77. doi: 10.1016/S0308-521X(02)00018-5

Hayman PT, Freebairn DM, Huda AKS (1996) Opportunity cropping on the Liverpool Plains: a comparison of risk assessment by farmers and simulation models. In 'Proceedings of the 8th Australian agronomy conference'. pp. 293-296. (Australian Society of Agronomy) 
Ihaka RI, Gerileman R (1996) R: a language for data analysis and graphics. Journal of Computational and Graphical Statistics 5, 299-314.

Jettner RJ, Walker SR, Churchett JD, Blamey FPC, Adkins SW, Bell K (1999) Plant sensitivity to atrazine and chlorsulfuron residues in a soil-free system. Weed Research 39, 287-295. doi: 10.1046/j.13653180.1999.00145.x

Jones RE, Medd RW (2000) Economic thresholds and the case for longer term approaches to population management of weeds. Weed Technology 14, 337-350.

Jongman RHG, ter Braak CJF, van Tongeren OFR (1995) 'Data analysis in community and landscape ecology'. (Cambridge University Press: Cambridge)

Kenkel NC, Derksen DA, Thomas AG, Watson PR (2002) Multivariate analysis in weed science research. Weed Science 50, 281-292.

McCune B, Grace JB (2002). 'Analysis of ecological communities.' (MjM Software Design: Gleneden Beach)

Leeson JY, Sheard JW, Thomas AG (2000) Weed communities associated with arable Saskatchewan farm management systems. Canadian Journal of Plant Science 80, 177-185.

Marcellos H, Felton WL (1992) Cropping systems of the temperate summer rainfall region. In 'Proceedings of the 6th Australian agronomy conference'. pp. 48-53. (Australian Society of Agronomy)

Martin RJ, McMillan MG, Cook JB (1988) Survey of farm management practices of the northern wheat belt of New South Wales. Australian Journal of Experimental Agriculture 28, 499-509.

Medd RW (1987) Conservation tillage and weed revolutions. Plant Protection Quarterly 21, 31-34.

Medd RW (1997) Biological constraints: weeds. In 'Sustainable crop production in the sub-tropics'. (Eds AL Clarke, PB Wylie) pp. 131-149. (Department of Primary Industries Queensland: Brisbane)

Medd RW, Martin RJ, Felton WL (1995) Herbicide tolerant crops: opportunities and concerns for the summer rainfall grain belt in Australia. In 'Herbicide-resistant crops and pastures in Australian farming systems'. (Eds GD McLean, G Evans) pp. 139-158. (Australian Government Publishing Service: Canberra)

O'Donnell CC, Adkins SW, Walker SR (2002) Herbicide resistance in the northern grain region of Australia: developments in research from 1993 to present. In 'Proceedings of the 13th Australian weeds conference'. (Eds H Spafford Jacob, J Dodd, J Moore) pp. 617-619. (Plant Protection Society of WA: Perth)
Radford BJ, Key AJ, Robertson LN, Thomas GA (1995) Conservation tillage increases in soil water storage, soil animal populations, grain yield, and response to fertiliser in the semi-arid subtropics. Australian Journal of Experimental Agriculture 35, 223-232.

Rew LJ, Alston CL, Harden S, Felton WL (2000) Counts versus categories: choosing the more appropriate weed scoring method. Australian Journal of Experimental Agriculture 40, 1121-1129. doi: 10.1071/EA00079

Storrie A, Cook A (2002) Glyphosate resistance in northern New South Wales - a growing concern. In 'Proceedings of the 13th Australian weeds conference'. (Eds H Spafford Jacob, J Dodd, J Moore) pp. 601-603. (Plant Protection Society of WA: Perth)

Storrie A, Walker SR (1999) Coping with the threat of herbicide resistance in weeds. In 'Proceedings of the 2 nd national conservation farming and minimum tillage conference'. pp. 39-44. (Conservation Farmers Inc. and Moree Conservation Farmers Association: NSW)

ter Braak CJF (1995) Ordination. In 'Data analysis in community and landscape ecology'. (Eds RHG Jongman, CJF ter Braak, OFR van Tongeren) pp. 91-173. (Cambridge University Press: Cambridge)

Walker SR, Barnes JE, Osten VA, Churchett JD, McCosker M (2000) Crop responses to sulfonylurea residues in soils of the subtropical grain region of Australia. Australian Journal of Experimental Agriculture 51, 587-596. doi: 10.1071/AR99040

Webb AA, Grundy MJ, Powell B, Littleboy M (1997) The Australian subtropical cereal belt: soils, climate and agriculture. In 'Sustainable crop production in the sub-tropics'. (Eds AL Clarke, PB Wylie) pp. 8-23. (Department of Primary Industries Queensland: Brisbane)

Wicks GA, Felton WL, Murison RD, Martin RJ (2000) Changes in fallow weed species in continuous wheat in northern New South Wales, 1981-90. Australian Journal of Experimental Agriculture 40, 831-842. doi: 10.1071/EA99105

Woodruff DR (1992) 'WHEATMAN' a decision support system for wheat management in subtropical Australia. Australian Journal of Agricultural Research 43, 1483-1499. doi: 10.1071/AR9921483

Received 20 December 2003, accepted 17 September 2004 
Appendix 1. Relative abundance of species, listed alphabetically by scientific name, recorded in the Liverpool Plains (L), Moree (M), Goondiwindi (G) and Kingaroy (K) regions within the subtropical grain region of Australia

Values are means for the total study period of May 1997 to July 2000

Species nomenclature follows the Flora of New South Wales (Harden 1990, 2002)

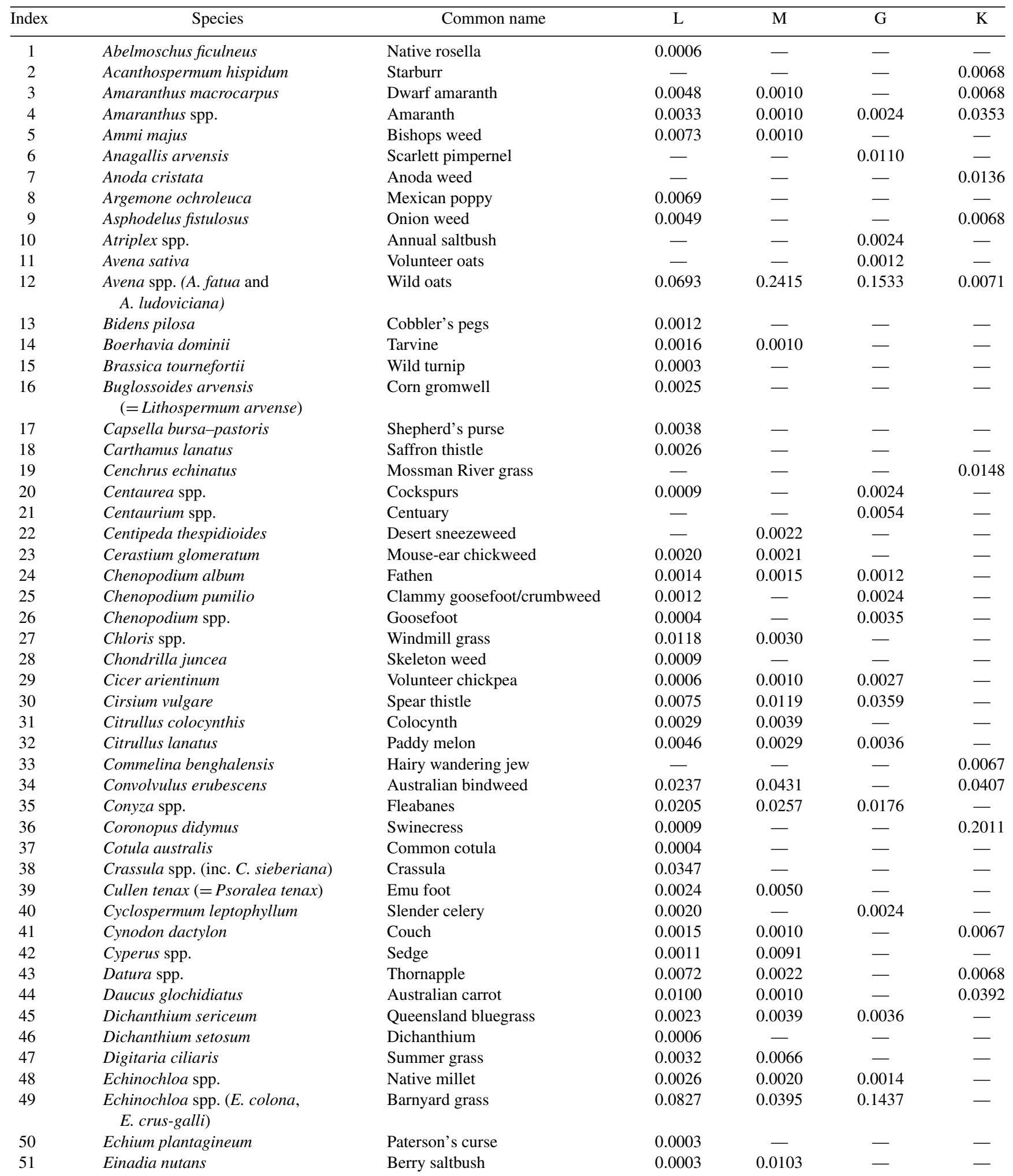


Appendix 1. Continued

\begin{tabular}{|c|c|c|c|c|c|c|}
\hline Index & Species & Common name & $\mathrm{L}$ & $\mathrm{M}$ & $\mathrm{G}$ & $\mathrm{K}$ \\
\hline 52 & $\begin{array}{l}\text { Einadia trigonos } \\
\quad(=\text { Chenopodium trigonos })\end{array}$ & Fishweed & - & - & 0.0012 & - \\
\hline 53 & Eleusine indica & Crowsfoot grass & - & - & 0.0012 & - \\
\hline 54 & Emex australis & Spiny emex & - & - & 0.0024 & 0.0213 \\
\hline 55 & $\begin{array}{l}\text { Epilobium hirtigerum and } \\
\text { E. billardierianum subsp. cinereum }\end{array}$ & Hoary willowherb & 0.0018 & 0.0010 & - & - \\
\hline 56 & Eriochloa pseudoacrotricha & Early spring grass & - & 0.0011 & - & - \\
\hline 57 & Erodium spp. & Crowsfoot & 0.0006 & - & - & 0.0224 \\
\hline 58 & $\begin{array}{l}\text { Euchiton and Gamochaeta spp. } \\
\text { (inc. E. sphaericus, G. spicata) }\end{array}$ & Cudweeds & 0.0124 & 0.0203 & 0.0237 & - \\
\hline 59 & Euphorbia spp. & Euphorbia & 0.0101 & 0.0099 & 0.0267 & - \\
\hline 60 & Fallopia convolvulus & Black bindweed & 0.0438 & 0.0160 & - & - \\
\hline 61 & Flaveria australasica & Yellow twin-stem/speedy weed & 0.0018 & - & 0.0050 & - \\
\hline 62 & Fumaria densiflora & Fumitory & 0.0012 & - & - & - \\
\hline 63 & Galium aparine & Cleavers & 0.0003 & - & - & - \\
\hline 64 & Geranium molle & Dove's foot cranesbill & 0.0003 & - & - & - \\
\hline 65 & Geranium solanderi & Australian cranesbill & 0.0003 & - & - & - \\
\hline 66 & Glycine $\max$ & Volunteer soybean & - & - & - & 0.0598 \\
\hline 67 & Gossypium hirsutum & Volunteer cotton & - & 0.0025 & - & - \\
\hline 68 & Haloragis spp. & Raspweed & 0.0073 & 0.0010 & - & - \\
\hline 69 & Helianthus annuus & Native sunflower & 0.0003 & 0.0010 & - & - \\
\hline 70 & Helianthus annuus & Volunteer sunflowers & 0.0027 & - & - & - \\
\hline 71 & Hibiscus trionum & Bladder ketmia & 0.0099 & 0.0061 & - & - \\
\hline 72 & Hordeum spp. & Barley grass & 0.0003 & - & - & - \\
\hline 73 & Hordeum vulgare & Volunteer barley & 0.0003 & - & - & - \\
\hline 74 & Hypochaeris glabra & Smooth catsear/flatweed & - & - & 0.0099 & - \\
\hline 75 & Hypochaeris radicata & Flatweed/common catsear & 0.0142 & 0.0052 & 0.0013 & - \\
\hline 76 & $\begin{array}{l}\text { Ibicella, Martynia } \\
\text { and Proboscidea spp. }\end{array}$ & Devil's claw & 0.0003 & - & - & - \\
\hline 77 & Ipomoea lonchophylla & Cowvine & 0.0013 & 0.0049 & - & - \\
\hline 78 & Ipomoea plebeia & Bellvine & - & 0.0010 & - & 0.0345 \\
\hline 79 & Iseilema membranaceum & Small flinders grass & - & 0.0020 & - & - \\
\hline 80 & Lactuca saligna & Willow lettuce & 0.0006 & - & - & - \\
\hline 81 & Lactuca serriola & Prickly lettuce & 0.0233 & 0.0238 & 0.0012 & - \\
\hline 82 & Lamium amplexicaule & Deadnettle & 0.2306 & 0.0010 & 0.0012 & 0.1288 \\
\hline 83 & Lepidium spp. (mainly bonariense) & Peppercress & 0.0003 & 0.0020 & 0.0071 & - \\
\hline 84 & Leptochloa divaricatissima & Cane grass & - & - & 0.0012 & - \\
\hline 85 & Lolium spp. & Ryegrass & 0.0123 & - & - & - \\
\hline 86 & Malva parviflora & Small flowered mallow/marshmallow & 0.0087 & 0.0045 & 0.0071 & - \\
\hline 87 & Malvastrum spp. & Malvastrum & 0.0008 & - & 0.0048 & - \\
\hline 88 & Marrubium vulgare & Horehound & 0.0009 & - & - & - \\
\hline 89 & $\begin{array}{l}\text { Medicago spp. (M. minima, } \\
\text { M. polymorpha) }\end{array}$ & Medics & 0.0181 & 0.0482 & 0.0118 & - \\
\hline 90 & Onopordum acanthium & Scotch thistle & 0.0003 & - & - & - \\
\hline 91 & Oxalis spp. & Oxalis & 0.0023 & 0.0080 & 0.0036 & - \\
\hline 92 & Panicum spp. & Panics & 0.0054 & 0.0065 & - & - \\
\hline 93 & Papaver spp. & Poppy & 0.0009 & - & - & - \\
\hline 94 & Phalaris paradoxa & Paradoxa grass & 0.0190 & 0.0684 & 0.0651 & - \\
\hline 95 & Phaseolus vulgaris & Volunteer navy bean & - & - & - & 0.0136 \\
\hline 96 & Physalis spp. & Ground cherries & - & 0.0010 & 0.0037 & 0.0067 \\
\hline 97 & Picris hieracioides & Hawkweed & 0.0003 & - & - & - \\
\hline 98 & Роа аппиа & Winter grass & 0.0019 & - & - & - \\
\hline 99 & $\begin{array}{l}\text { Polygonum spp. } \\
\quad \text { (P. aviculare, P. patulum) }\end{array}$ & Wireweed, tree hogweed & 0.0200 & 0.0283 & 0.0050 & - \\
\hline 100 & Portulaca oleracea & Pigweed & 0.0058 & 0.0029 & 0.0024 & - \\
\hline 101 & Raphanus raphanistrum & Wild radish & 0.0071 & 0.0124 & 0.0024 & 0.1432 \\
\hline
\end{tabular}


Appendix 1. Continued

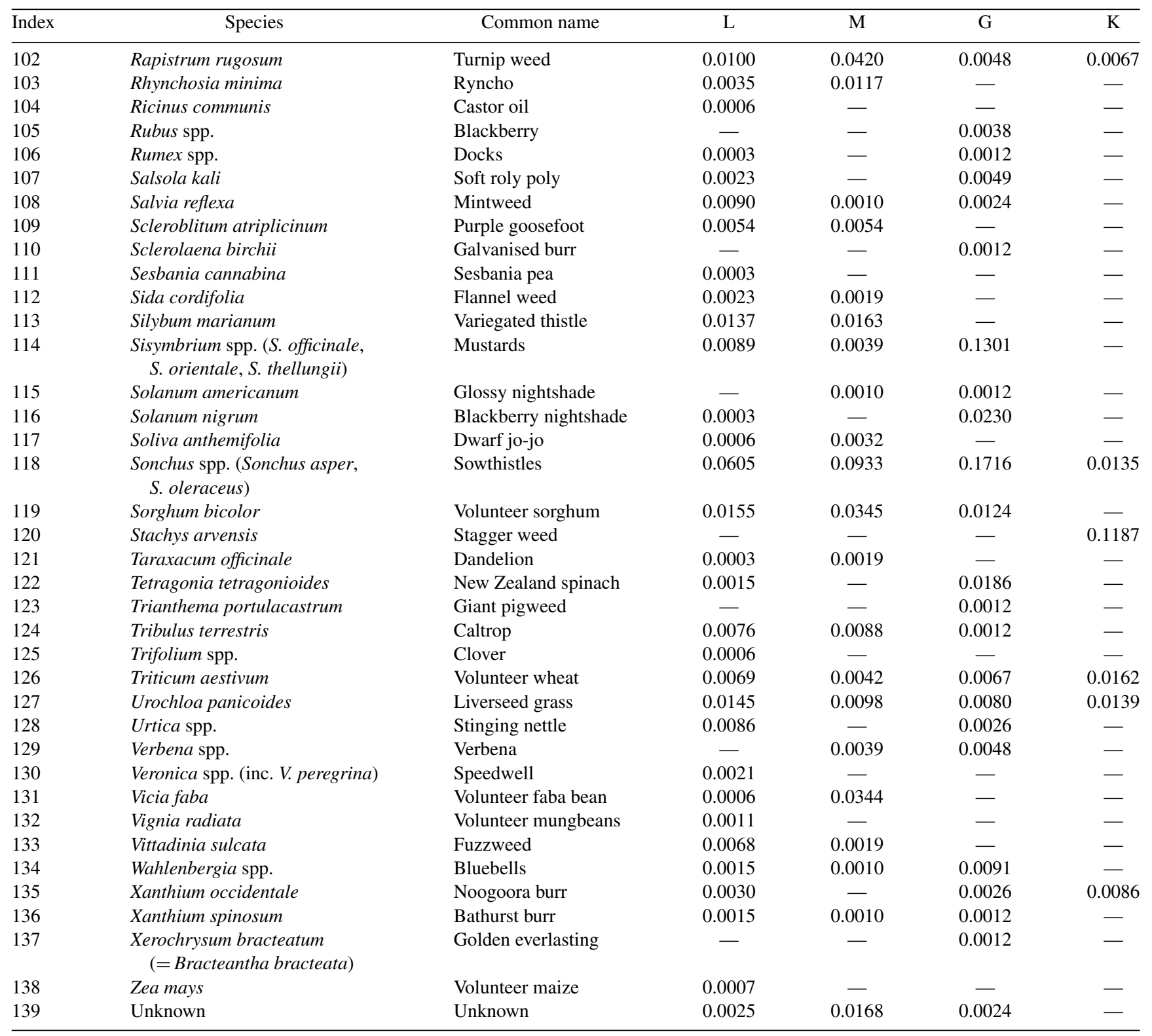

